\title{
PLA Bioplastic Start-uP - A CAPSTONe PROJECT That GALVANIZED Motivation
}

\author{
Antoine Côté, Jérémie Morneau \\ Département de mathématiques, informatique et genie, Université du Québec à Rimouski \\ Antoine.cote@uqar.ca
}

As students are about to graduate, motivation may be difficult to find. The present work showcases how a team used a capstone project to galvanize their motivation, having gained knowledge in fields out of their own. The project is still pursued past graduation, as the team is embarking on a business start-up. The end result was an unconventional way to mindset students, stimulating their curiosity, entrepreneurship and willingness to learn.

Engineering programs at Université du Québec à Rimouski (UQAR) are project oriented. From the baccalaureate's first year until graduation, students get involved with real clients, delivering prototypes used in production. Projects are the cornerstone of engineering education. As students make complex choices, they develop autonomy, confidence and competence. By overcoming difficulties in a complex task, they also get a glimpse of labour market.

In UQAR's capstone projects, students are usually given a conception task with an industrial partner. Two undergraduates (mechanical and electro-mechanical engineering) chose to work on a personal entrepreneurial project and considered the viability of establishing a bioplastic plant. The subject emerged from two business opportunities: the lack of such industry in the region, and a landfill ban for organics by 2020 [1]. Students had limited background in chemistry, and only had one semester to scope and hand in the project.

Goals were broad: a bioplastic (PLA) was to be obtained from local resources, without diverting edible matter, and synthetized by a process of minimal environmental impact. Requirements were sustainability of the process, the ability to scale it up, and the versatility of the end product.

A detailed layout, a techno-economical study and a business plan were produced in limited time. The results showcased innovative solutions. Bacteria were selected instead of a classical chemical synthesis, saving up to $273 \mathrm{~T}$ of waste for a $150 \mathrm{~T}$ annual production [3]. Use of a twin-screw extruder was also planned, promising enhanced mechanical and thermal properties [2]. Final cost of production was evaluated at 4,60\$/kg, suggesting a $55 \%$ profit margin based on actual PLA prices [4].
Students had limited background in chemistry. They teamed up with a graduate in chemistry, who, among other things, helped define relevant keywords for the literature review. Other local actors were involved, such as SEREX (Applied research center in forest products processing), CRABE (Research collective in bioprocesses and environmental chemistry), UQAR's NSERC Design Chair, and professors from management and chemistry departments. The graduate student in chemistry was inspired by the initiative, and he is currently thinking about doing a master's degree on the subject.

Students learnt how to undertake an effective literature review. They also adapted a project management methodology inspired from Ulrich [5]. By consulting a graduate, they were able to define a research framework of a broad project (launching an industry). Practical milestones organized on a Gantt chart helped figuring out when to stop searching and when to move on. Students got exposed to fields out of their own, like industrial engineering, management and chemistry.

Students gained a lot from their experience. They developed autonomy, entrepreneurship and curiosity. They also experienced the strength of teamwork, as members would motivate each other in difficult moments, or divide tasks to tackle problems on multiple fronts.

For continuous improvement, Ulrich points out how important it is to "reflect on the result and the process" [5]. Looking back at a project oftenly shows more efficient ways to solve a problem, acquire knowledge and develop skills through a self-reinforcing spiral process. As John Powel wisely said, "the only real mistake is the one from which we learn nothing." Projects are inevitably subject to error, and oftenly lead to creative solutions. This is probably why they are such a remarkable learning tool.

Engineering programs teaches a lot to students. Still, it seems that projects are the most valuable way to teach students how to overcome difficulties and develop new skills - to learn how to learn. No training can prepare for every challenge future engineers will face. Adaptation is key, and the present project is a sound example. 


\section{Acknowledgements}

This project was largely made possible by UQAR's NSERC Design Chair, Entrepreneuriat UQAR, and M. Gabriel Chiriță, who strongly believed in the team since the outset of the project. We would like to thank professors Jean Brousseau and Jean-Sébastien Deschênes, our devoted supervisors. We also specially thank M. LouisCharles Lapierre, who has been invaluable in its support. He brought clarity to the project, and opened our minds.

\section{References}

[1] Gouvernement du Québec, "Politique québécoise de gestion des matières résiduelles," Environnement et Lutte contre les changements climatiques.

Available as of April 17th, 2019, from http://www.environnement.gouv.qc.ca/matieres/pgmr/

[2] Yunzi Hu et al, "Newly Developed Techniques on Polycondensation, Ring-Opening Polymerization and Polymer Modification: Focus on Poly(Lactic Acid)," Materials, 2016, $14 \mathrm{p}$.

[3] K. Madhavan Nampoothiri, et al., "An overview of the recent developments in polylactide (PLA) research," Bioresource Technology, 2010, 9 p.

[4] Plastic Insights, "Polylactic Acid Properties, Production, Market and Uses"

Available as of January 13th, 2019, from https://www.plasticsinsight.com/resin-intelligence/resinprices/polylactic-acid/

[5] Karl T. Ulrich, Steven D. Eppinger, Product Design and Development. New York, McGraw-Hill, 2000 (2nd ed.), $358 \mathrm{pp}$. 